\title{
Serology, polymerase chain reaction and histopathology for leptospirosis in samples collected at slaughter from dairy cows of Parnaiba region, state of Piauí, Brazil ${ }^{1}$
}

\author{
Ana Lys Bezerra Barrradas Mineiro², Rômulo José Vieira², Érica Azevedo Costa ${ }^{3}$, \\ Renato Lima Santos ${ }^{3}$, Larissa Maria Feitosa Gonçalves ${ }^{2}$, Sônia Maria Carvalho², \\ Maria Rosa Quaresma Bomfim ${ }^{3}$ e Francisco Assis Lima Costa ${ }^{2 *}$
}

\begin{abstract}
Mineiro A.L.B.B., Vieira R.J., Costa E.A., Santos R.L., Gonçalves L.M.F., Carvalho S.M., Bomfim M.R.Q. \& Costa F.A.L. 2011. Serology, polymerase chain reaction and histopathology for leptospirosis in samples collected at slaughter from dairy cows of Parnaiba region, state of Piauí, Brazil. Pesquisa Veterinária Brasileira 31(10):859-866. Departamento de Clínica e Cirurgia Veterinária, Centro de Ciências Agrárias, Universidade Federal do Piauí, Campus da Socopo, Bairro Ininga, Teresina, PI 64049-550, Brazil. E-mail: fassisle@gmail.com

The presence of anti leptospiral agglutinins (microscopic agglutination test - MAT) and DNA of leptospires was investigated in the kidney and urine (Polymerase Chain Reaction PCR) in samples collected at the time of slaughter of cattle originating from the dairy basin of Parnaíba, Piauí, Brazil, as also the lesions in kidney, lung, liver, uterus, ovary and placenta (histopathology and immunohistochemistry). In the MAT, Hardjo was the predominant serovar with the highest number of reagent animals for the strain Hardjobovis/Sponselee. Anti-leptospiral antigens were scored in epithelial cells, interstitial vascular endothelium, endothelium of glomerular capillaries and Bowman's capsule of 20 positive animals. Inflammatory cells were more common in the kidney. PCR was positive in urine and kidney tissue.
\end{abstract}

INDEX TERMS: Leptospirosis, immunohistochemistry, PCR, cattle.

RESUMO.- [Sorologia, reação em cadeia da polimerase e histopatologia para leptospirose em amostras coletadas de vacas leiteiras, em matadouro da região de Parnaíba, Piauí.] Foi investigada a presença de aglutininas anti leptospiras (reação de soroaglutinação microscópica SAM), de DNA de leptospiras no rim e na urina (reação de cadeia pela polimerase - PCR), bem como de lesões no rim, pulmão, fígado, útero, ovário e placenta (histopatologia e imunohistoquímica), em materiais colhidos, por ocasião do abate, de bovinos originários da bacia leiteira da região de Parnaíba, Piauí, Brasil. Na SAM o sorovar predominante foi o Hardjo com maior número de animais reagentes para a

\footnotetext{
${ }^{1}$ Received on April 18, 2011.

Accepted for publication on June 20, 2011.

${ }^{2}$ Departamento de Clínica e Cirurgia Veterinária, Setor de Patologia Animal, Centro de Ciências Agrárias, Universidade Federal do Piauí, Campus da Socopo, Bairro Ininga, Teresina, PI 64049-550, Brazil. *Corresponding author: fassisle@gmail.com

${ }^{3}$ Departamento de Clínica e Cirurgia Veterinária, Escola de Veterinária, Universidade Federal de Minas Gerais, Av. Antonio Carlos 6627, Pampulha, Cx. Postal 567, Belo Horizonte, MG 31270-901, Brazil.
}

estirpe Hardjobovis/Sponselee. Antígenos anti leptospira foram marcados em 20 animais positivos nas células epiteliais e do endotélio vascular, endotélio dos capilares glomerulares e na cápsula de Bowman, somente nos animais infectados. 0 infiltrado inflamatório foi maior no rim do que nos demais órgãos. A PCR foi positiva em amostras de urina e tecido renal.

TERMOS DE INDEXAÇÃO: Leptospirose, imuno-histoquímica, PCR, bovino.

\section{INTRODUCTION}

Leptospirosis is considered one of the major diseases that affect the reproductive system, primarily causing abortion, infertility, stillbirth and retained placenta in reproduction animals as bovine and swine. It is one of the main causes of low livestock productivity both nationally and globally (Givens 2006).

Cattle are considered maintenance hosts of the serovar Hardjo (Moreira et al. 2004). In addition to a high susceptibility to infection and low pathogenicity, transmission of 
Hardjo is endemic in these animals. That is why the disease is chronic and characterized by reproductive disorders. Serovar Hardjo has two distinct genotypes: Hardjobovis and Hardjoprajitno. The genotype Hardjobovis belongs to the species Leptospira borgpetersenii, while the genotype Hardjoprajitno belongs to the species L. interrogans. Both are important causes of reproductive disorders in cattle herds worldwide and have different clinical manifestations (Faine 1999). Hardjobovis infection is considered pandemic in cattle and it is often characterized by a subclinical form with classic signs of abortion. Hardjoprajitno has been isolated in a few countries and is more pathogenic, leading to a drop in milk production and reproductive disorders (Ellis 1994).

The lesions caused by Leptospira spp are observed mainly in the kidneys where the organism arrives via the bloodstream. In the kidneys, the species multiplies, causing tubulointerstitial lesions (Scanziani et al. 1989, Yang et al. 2001). In the leptospiremic phase, the liver is the first site to be reached by the organism where it causes necrosis of liver cells, intrahepatic cholestasis resulting in decreased liver bilirubin excretion (Wohl 1996, Faine et al. 2001). On electron microscopy of the lungs, the primary lesion is found in capillary endothelial cells (Huttner et al. 2002). During the inflammation process, lung injury has been associated with over-stimulated cells including alveolar macrophages, polymorphonuclear cells and the production of reactive oxygen and nitrogen species or other inflammatory mediators (Nally et al. 2004).

The accurate diagnosis of leptospiral infection in cattle is dependent on isolation and typing of the prevalent serovar. However, only serological surveys have been conducted in the majority of studies published in Brazil. MAT was used to detect antibodies against leptospires. However, this test has some limitations since it does not identify the specific genotype. Leptospires can be detected in the urine and viscera by using the antigen-antibody interaction labeled with immunoperoxidase staining (Baskerville 1984).

Among the diagnostic techniques based on detection of Leptospira DNA, polymerase chain reaction (PCR) has been increasingly used for diagnosis in fluids and organs of various animal species (Heinemann et al. 1999).

The aim of this study was to research anti-Leptospira agglutinins (L. interrogans) in cows from the dairy basin of the Parnaiba region in the state of Piauí, characterize the possible damage in their kidneys, liver, lungs, ovaries, uterus and placenta; detect the presence of leptospiral antigen, as well as the presence of Leptospira DNA in the kidneys and urine.

\section{MATERIALS AND METHODS}

A total of 60 adult cows from the dairy basin of the Parnaiba region in the state of Piauí were used. The animals were slaughtered to consumption, according to technical recommendations of the Ministry of Agriculture, Cattle Breeding and Supply (MACBS) (Brasil 2000), from July 2007 to July 2008.

For performance of the microscopic agglutination test (MAT), blood samples were collected from these animals during blee- ding in the slaughterhouse. To obtain serum, blood samples were maintained in $10 \mathrm{~mL}$ tubes free of anticoagulant, centrifuged at $10000 \mathrm{x}$ g for 10 minutes. The serum was then placed in $1.5 \mathrm{~mL}$ microtubes and subsequently stored at $-20^{\circ} \mathrm{C}$ until batching.

Tissue samples were collected from the kidneys, liver, lungs, ovaries, uterus and placenta of the slaughtered animals. Tissue sections were approximately $0.5 \mathrm{~cm}$ thick, fixed in $10 \%$ neutral formalin, buffered with $0.01 \mathrm{M}$ phosphate $\mathrm{pH} 7.4$ (buffered formalin) and Bouin's fixative. Kidney samples were collected and placed in Duboscq-Brazil solution for 60 minutes and maintained in $10 \%$ neutral buffered formalin until processing.

Sections of kidneys, liver, lung, ovaries, uterus and placenta were processed and stained with hematoxylin-eosin (HE), Periodic Acid Schiff (PAS), Masson's trichrome (Masson) and Periodic Acid Metanamine Silver (PAMS.) following standard technique (Luna 1968). Slides were also treated with adhesive Silane A174 (3-aminopropriltrietoxi-silano, Sigma Chemical C.O., St. Louis, MO, USA) for application of immunoperoxidase technique to kidney specimens fixed only in buffered formalin. For detection of Leptospira DNA, 30mg of kidney sections were placed in cryogenic tubes with RPMI and 10\% glycerol for storage in liquid nitrogen until processing.

Serological diagnosis of Leptospira infection was performed in the Laboratory of Zoonosis, Universidade Federal de Minas Gerais, Belo Horizonte, MG, Brazil with live antigen collection, including 11 pathogenic serovars: Ballum, Bratislava, Canicola,, Grippotyphosa, Icterohaemorrhagiae, Szwajizak, Mini, Pomona and Hardjo (strains: Hardjobovis/Sponselee, Hardjoprajtino/CTG, Hardjoprajitno/OMS at 4-10 days of growth, diluted at a ratio of 1:3 in buffered saline, $\mathrm{pH} 7.2$ (Quadro 1).

Quadro 1. Strains used in the microscopic agglutination test, EV/UFMG

\begin{tabular}{lcc}
\hline \multicolumn{1}{c}{ Serogroup } & Serovar & Strain \\
\hline Australis & Bratislava & Jez Bratislava \\
Ballum & Ballum & Mus 127 \\
Canicola & Canicola & Hond Utrecht IV \\
Grippothyphosa & Gripothyphosa & Moskva V \\
Icterohaemorragiae & Icterohaemorragiae & RGA \\
Mini & Szwajizak & Szwajizak \\
Mini & Mini & Neguita \\
Pomona & Pomona & Pomona \\
Sejroe & Hardjo & Hardjoprajitno (OMS) \\
Sejroe & Hardjo & Hardjoprajitno (Norma) \\
Sejroe & Hardjo & (hardjobovis (Sponselee)
\end{tabular}

The sample was considered reactive when there were $50 \%$ agglutinated leptospires per microscopic field. The serovar that exhibited the highest titre was recorded. The remaining agglutinations were considered cross-reactions. Positive samples in the initial titer were again serially diluted to a ratio of two and tested for the serovar that had responded earlier. The final titre was defined by $50 \%$ or greater agglutination of Leptospira antigen. 20 negative animals in the MAT constituted the control group. The detection of leptospiral antigen was performed by immunoperoxidase technique. Tissue sections were dewaxed in xylene, gradually hydrated in decreasing ethanol concentrations and subjected to quenching of endogenous peroxidase with $0.03 \%$ hydrogen peroxide in methanol for $30 \mathrm{mi}$ nutes in the dark. These sections were treated with maximum microwave power in Tris- $\mathrm{HCl}$ solution, $(\mathrm{pH} 1.0)$, serially for 10 
and 5 minutes. After washing with phosphate buffered saline (PBS), sections were incubated with polyclonal rabbit anti-Leptospira antibody (produced in the Laboratory of Animal Pathology, Universidade Federal do Piauí, Teresina, Brazil) at a dilution of 1:200 in a humid atmosphere at $4^{\circ} \mathrm{C}$ overnight. On the following day, incubation with a secondary antibody and amplification reaction were performed with the EnVision ${ }^{\circledR}$ System Labelled Polymer, peroxidase (Dako Cytomation, cod. $\mathrm{K}$ 4001, Carpinteria, USA) in a humid atmosphere, at room temperature for 30 minutes. The reaction was developed with $0.3 \mathrm{mg} / \mathrm{ml}$ of diaminobenzidine (Sigma Chemical, USA) in PBS with $0.06 \%$ hydrogen peroxide and counterstained with Harris hematoxylin (Sigma Chemical, USA).

DNA extraction from renal tissue and urine samples was performed by optimizing DNA extraction method with silica. Renal tissue and urine samples were mixed with PBS in $1.5 \mathrm{ml}$ microtubes containing $1.0 \mu \mathrm{L}$ of Sodium Iodide (NaI). Samples were then incubated at $55^{\circ} \mathrm{C}$ for $15 \mathrm{~min}$, silica was added, mixed for $10 \mathrm{mi}$ and centrifuged at $14,000 \mathrm{x}$ g for $30 \mathrm{~s}$. The supernatant was discarded, added to $\mathrm{NaI}$ and centrifuged at $14,000 \mathrm{x} g$ for $30 \mathrm{~s}$. The supernatant was again discarded and added to the $1000 \mu \mathrm{L}$ ethanol washing solution. Excess ethanol was removed with $1000 \mathrm{~mL}$ of cold acetone, centrifuging at $14,000 \mathrm{x} g$ for $30 \mathrm{~s}$. DNA was resuspended from the cell pellet by adding $50 \mu \mathrm{L}$ autoclaved ultrapure water after incubation at $65{ }^{\circ} \mathrm{C}$ for 10 and centrifugation at $14000 \mathrm{x}$ g for 2 minutes. The total DNA recovered was stored in $-20^{\circ} \mathrm{C}$ until diagnostic testing. DNA concentration was estimated by measuring the absorbance at $260 \mathrm{~nm}$ using a GeneQuant spectrophotometer (Pharmacia, Piscataway, NJ).

The primers used were G1 (5'-CTGAATCGCTGTATAAAAGT-3') G2 (5'-GGAAAACAAATGGTCGGAAG-3'). These primers are traditionally known to be diagnostic of leptospirosis and were described by Gravekamp et al. (1993). PCR amplification was carried out in a total volume of $25 \mu \mathrm{L}$, containing $1.5 \mathrm{mM} \mathrm{MgCl}_{2}$ buffer, $200 \mathrm{mM}$ of each dNTP, $10 \mathrm{mM}$ of each primer, $2 \mathrm{U}$ of Platinum $\AA$ Taq DNA Polymerase (Invitrogen, California, USA), and 200ng of genomic DNA. Amplification was processed in a thermocycler with an initial cycle of $94^{\circ} \mathrm{C}$ for $3 \mathrm{~min}$ followed by 30 cycles of $94^{\circ} \mathrm{C}$ for $30 \mathrm{~s}, 51^{\circ} \mathrm{C}$ for $1 \mathrm{~min}$ and $72^{\circ} \mathrm{C}$ for $1 \mathrm{~min}$, with a final extension of $72^{\circ} \mathrm{C}$ for $7 \mathrm{~min}$. The PCR product was analyzed by electrophoresis in $1.5 \%$ agarose gel, stained with ethidium bromide $0.5 \mathrm{mg} /$ $\mathrm{ml}$ ) and visualized by UV trans-illuminator (Bioagency, São Paulo, Brazil).

Histopathological evaluation of the kidneys, liver, lungs, ovaries, uterus and placenta was performed by light microscopy in a semi-quantitative analysis, according to the location, distribution and intensity of lesions on a scale of 0 to 5 , where $0=$ normal, 1 = minimal, 2 = medium, 3 = moderate, $4=$ moderately severe, 5 = severe (Pirani 1994). Quantitative results were analyzed with Sigma Stat statistical software (Bioestat 5.0) for nonparametric tests: a) the Kruskal-Wallis method was used for analysis of variance. In the presence of significant differences, the Student-Newman-Keuls test was applied for multiple group comparisons b) the Mann-Whitney test was used for comparison between two groups. The level of significance was set at $\mathrm{p}<0.05$.

\section{RESULTS}

Sera of 60 cows were analyzed by the MAT. Of these, 23 were positive for one or more Leptospira spp. serovars and anti-Leptospira agglutinins were detected in $38.3 \%$ of serum samples. Among the reagents, the most frequent serovar was
Hardjo: Hardjobovis/Sponselee (15/23); Hardjoprajitno/CTG $(3 / 23)$ and Hardjoprajitno/OMS $(2 / 23)$ followed by Bratislava $(1 / 23)$, Icterohaemorragiae $(1 / 23)$. Antibody were diluted to $1: 100$ in nine animals, 1:200 in three animals, 1:400 in three animals, 1:800 in three animals, 1: 3200 in one animal and 1: 6400 in four animals. Animals that responded to genotypes Hardjobovis/Sponselee, Hardjoprajitno/CTG and Hardjoprajtno/OMS accounted for $86.9 \%$ (20/23), followed by serovars Bratislava, 4.34\% (1/23), Icterohaemorragiae 4.34\% (1/23) and Pomona 4.34\% (Quadro 2).

\section{Quadro 2. Distribution of anti-Leptospira (L. interrogans) serum titres in seropositive cows forevidence of MAS, according to the infecting serovars}

\begin{tabular}{ccccccc}
\hline Serovar & \multicolumn{5}{c}{ Titer } \\
\cline { 2 - 6 } & 100 & 200 & 400 & 800 & 3200 & 6400 \\
\hline $\begin{array}{c}\text { Hardjo } \\
\text { (Hardjobovis/Sponselee) } \\
\text { Hardjo }\end{array}$ & 9 & & & 2 & 1 & 3 \\
$\begin{array}{c}\text { (Hardjoprajitno/CTG) } \\
\text { Hardjo }\end{array}$ & 2 & & 1 & & \\
$\begin{array}{c}\text { (Hardjoprajitno/OMS } \\
\text { Bratislava }\end{array}$ & 1 & 1 & & 1 \\
$\begin{array}{c}\text { Icterohaemorragiae } \\
\text { Pomona }\end{array}$ & 1 & 1 & & \\
\hline
\end{tabular}

To analyze lesions in the kidneys, liver, lungs, ovaries, uterus and placenta, samples from 40 cows were used. Of these, 20 were serologically positive and 20 serologically negative (control group). All positive animals (100\%) showed tubulointerstitial alterations. Interstitial nephritis was present in all animals (100\%), with inflammatory infiltrate predominantly composed of lymphocytes, macrophages, plasma cells (Fig.1) and rare neutrophils. The intensity of lesions was more severe in infected animals than in uninfected animals ( $p<0.05$, Mann-Whitney test) (Fig.2). The lesion was located mainly in the corticomedullary junction, but also in the cortical and medullary area, but there were no significant difference between the regions. There were focal perivascular, periglomerular and peritubu-

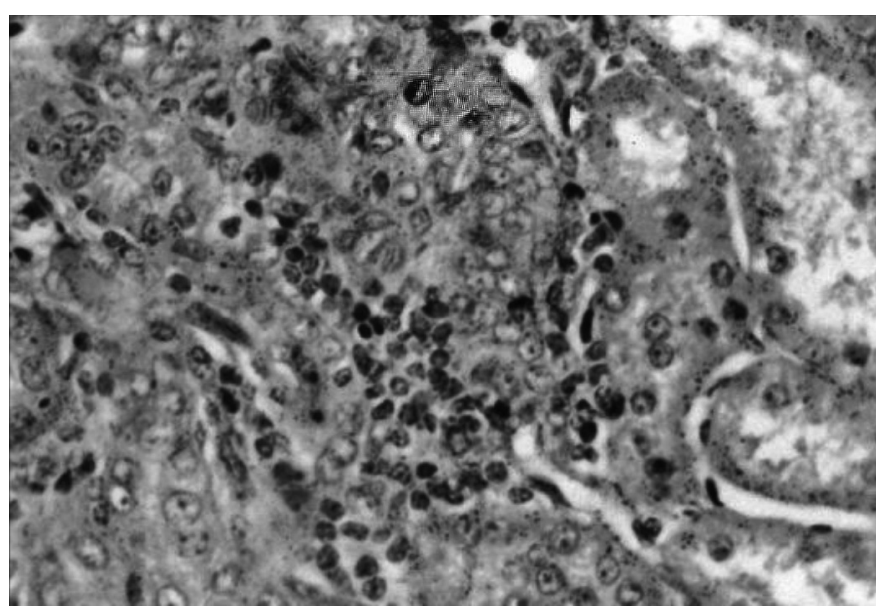

Fig.1. Kidney of cow naturally infected with Leptospira spp. Mononuclear interstitial infiltrate. HE stain, 40x. 


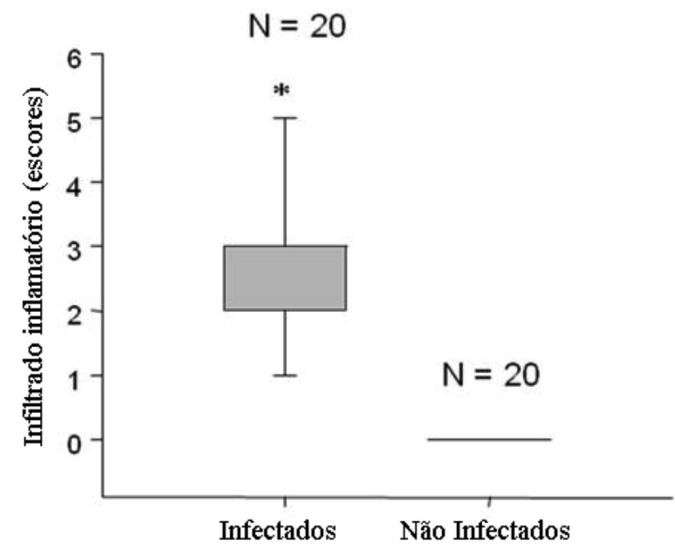

Fig.2. Semi-quantitative analysis of the intensity of inflammation (median scores and range between 25 and 75 percentiles) in the kidneys of dairy cows naturally infected by Leptospira spp and control. $\mathrm{N}=$ number of animals per group. $\mathrm{P}<0.05$ compared to control group (Mann-Whitney test).

lar lesions, ranging in intensity from minimal to severe. In the glomeruli, mainly focal segmental hypercellularity was observed. The glomerular tuff was lobulated. In rare cases, there was segmental thickening of the glomerular capillary basement membrane. There was also thickening of Bowman's capsule. Hyaline casts were present in the kidney tubules of eight animals (34.78\%). Necrosis of the basement membrane, atrophy and vasculitis occurred in six animals $(26.08 \%)$.

In five cases $(21.73 \%)$, leptospires were detected by the Warthin-Starry technique in the proximal tubular lumen. Leptospires were grouped into black masses, lying free in the lumen and adhering to the surface of the tubular epithelium (Fig.3).

Histopathological examination of the lungs revealed inflammatory infiltrate mainly composed of macrophages and lymphocytes in all lobes of seroreactive animals. Neutrophils and eosinophils were also present in some cases. Inflammatory infiltrate was located in the peribronchial and peribronchiolar regions and had a higher intensity in seroreactive animals than in seronegative animals $(\mathrm{p}<0.05$, Mann-Whitney

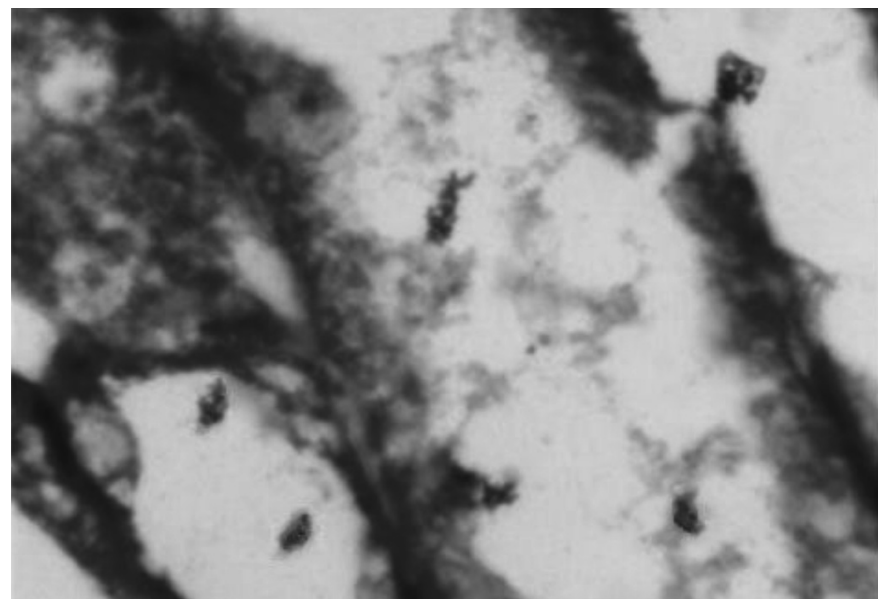

Fig.3. Kidney of cow naturally infected with Leptospira spp. Presence of leptospires adhered to the luminal surface of the proximal tubule, in the form of pellets. Warthin Starry stain, 350x test). Interalveolar septal thickening of focal distribution were also changes observed in lung tissue. In rare cases, diffuse congestion, hemorrhage, pulmonary edema and exudate in the bronchial and bronchiolar lumen were also visualized.

In the liver, inflammatory infiltration mainly composed of lymphocytes and macrophages was observed in all study animals. Lesions were located in the periportal region, varying in intensity from minimal to moderate. There were no significant differences between seropositive and seronegative animals. Hyperplasia of Kupffer cells was found in eight positive animals and in two negative animals.

Histopathological examination of the uterus showed diffuse lymphocytic infiltrate with a higher intensity in positive animals than in control animals $(p<0.05$, Mann-Whitney test) (Fig.4). Thick-walled arteries and foamy cells, endometrial glands with swollen and vacuolated epithelium were observed. The infiltrate was located in the perivascular and periglandular regions. The inflammatory reaction was usually associated with congestion and edema. In other cases, it was accompanied by periglandular fibrosis with a variable degree of glandular dilatation.

All seropositive animals exhibited pathological changes in the ovaries characterized by mononuclear inflammatory infiltrate (Fig.5). It was a focal process in all cases and there was no difference between the 20 positive and 20 negative animals (control group). Lesions such as fibrosis were found in 10 positive animals (Fig.6).

In the placenta, mononuclear inflammatory infiltrate cells were observed between the villi, neutrophils and eosinophils, necrosis of chorionic villi and amorphous material on the chorion.

In general, analysis of inflammatory response in various organs examined in conjunction revealed a higher lymphohistiocytic and plasma cell inflammatory infiltrate in infected animals compared to uninfected controls $(\mathrm{p}<0.05$, Mann-Whitney test) (Fig.7).

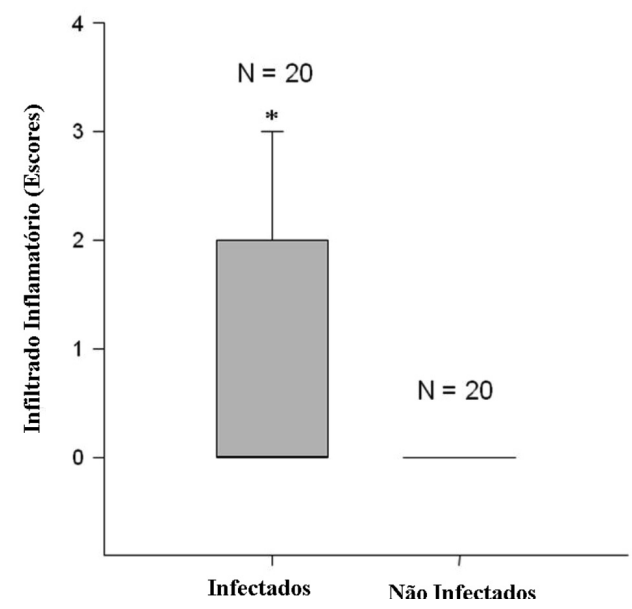

Fig. 4. Semi-quantitative analysis of inflammatory infiltrate (median percentile scores between 25 and 75) in the uterus of dairy cows naturally infected with Leptospira spp and uninfected control. $\mathrm{N}=$ number of animals per group. ${ }^{*} \mathrm{P}<0.05$ (Mann Whitney test). 


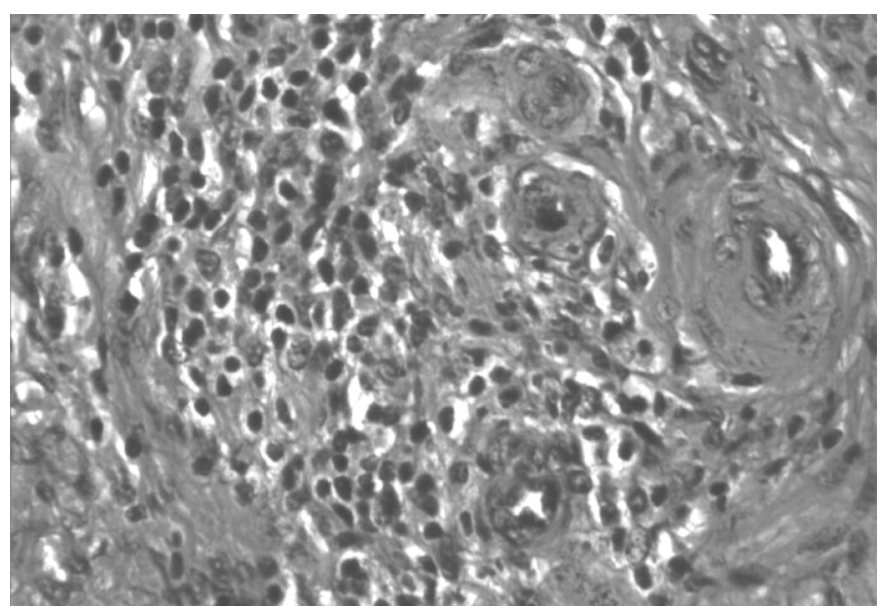

Fig.5. Ovary of cow naturally infected with Leptospira spp. Acute focal inflammatory infiltrate. HE stain, 40x.

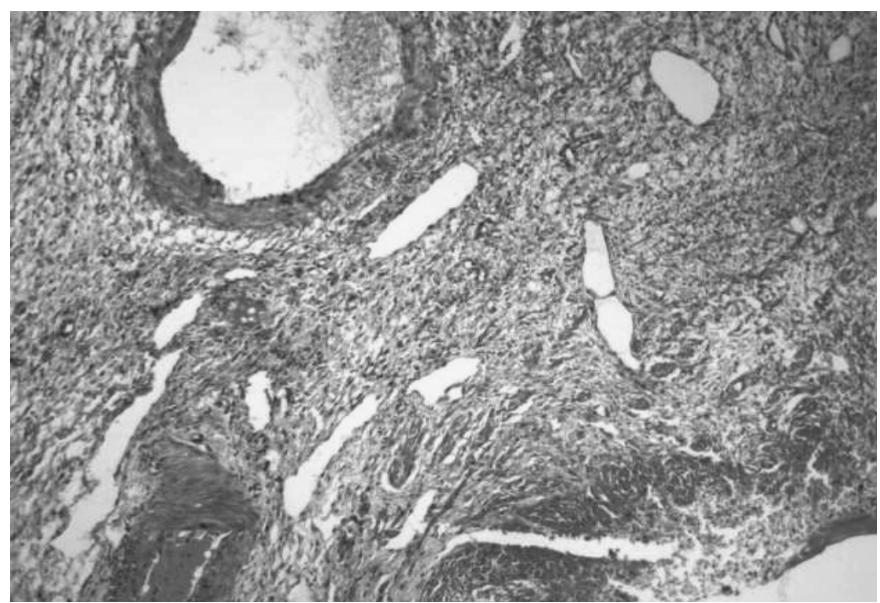

Fig.6. Ovary of cow naturally infected with Leptospira sp. Fibrosis. Masson, 40x.

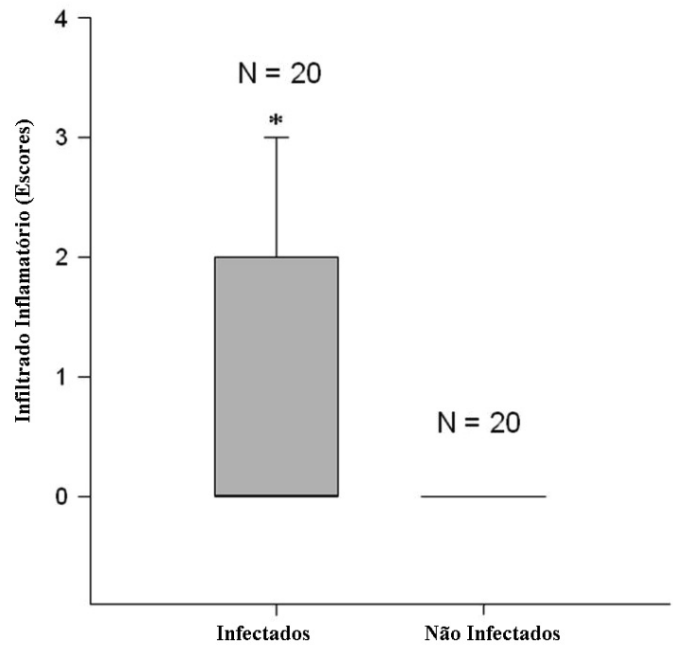

Fig.7. Semi-quantitative analysis of the inflammatory infiltrate (median scores between 25 and 75 percentiles) of dairy cows naturally infected by Leptospira spp and uninfected control. $\mathrm{N}=$ number of animals per group. ${ }^{*} \mathrm{P}<0.05($ Mann Whitney test).
Inflammatory cells were present in greater intensity in the kidney followed by the lung, liver, uterus, ovary and placenta $(\mathrm{p}<0.05$, Kruskal-Wallis and Student-Newman-Keuls test) (Fig.8).

Immunohistochemistry performed in 40 animals (20 soropositive and 20 soronegative) revealed Leptospira sp. antigen in epithelial cells, interstitial vascular endothelium, glomerular capillary endothelium and Bowman's capsule (Fig.9), only in infected animals ( $\mathrm{p}<0,05$, Mann-Whitney) (Fig.10).

PCR performed on urine samples from 40 animals showed 20 serologically positive and 20 serologically negative animals. The test was positive in all infected animals and negative in all uninfected animals (Fig.11). PCR performed on kidney samples of those animals was positive in only 10 of the infected animals and negative in all uninfected animals.

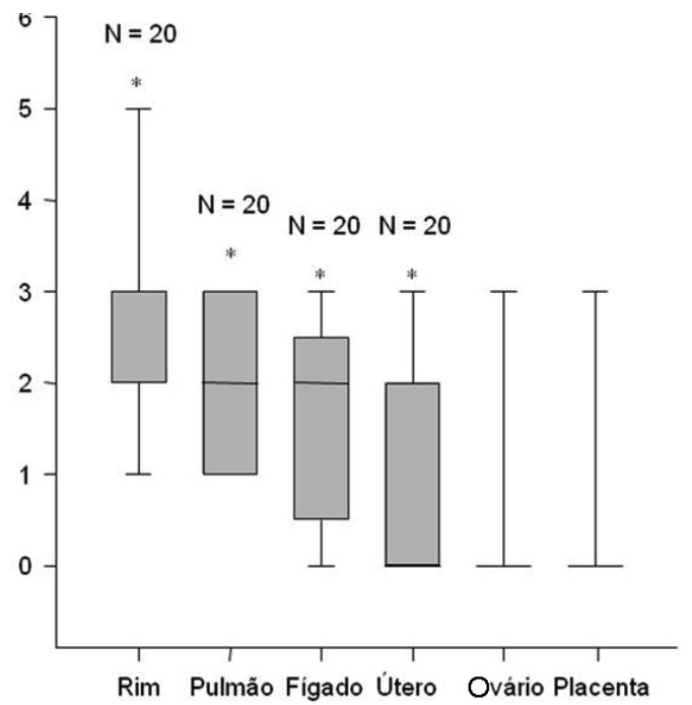

Fig.8. Semi-quantitative analysis of the inflammatory infiltrate (median scores between 25 and 75 percentiles) in kidney, lung, liver, uterus, ovary and placenta in dairy cows naturally infected by L. spp and uninfected control. $\mathrm{N}=$ number of animals per group. ${ }^{*} \mathrm{P}<0.05$ (Kruskal-Wallis and Student-Newman-Keuls).

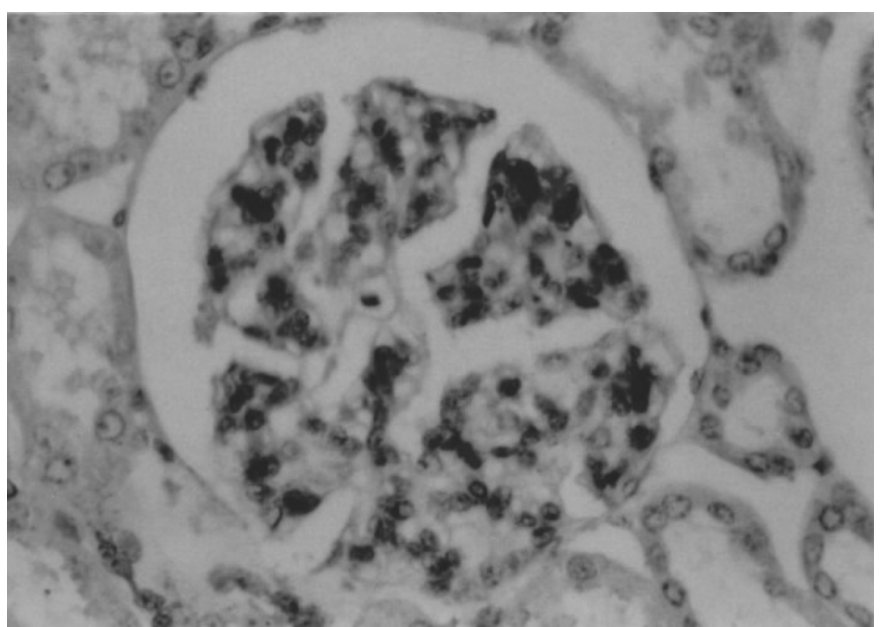

Fig.9. Kidney of cow naturally infected with Leptospira spp. Presence of antigens in the glomerulus. Immunoperoxidase staining was performed. Sections were counterstained with Harris hematoxylin, 40x. 


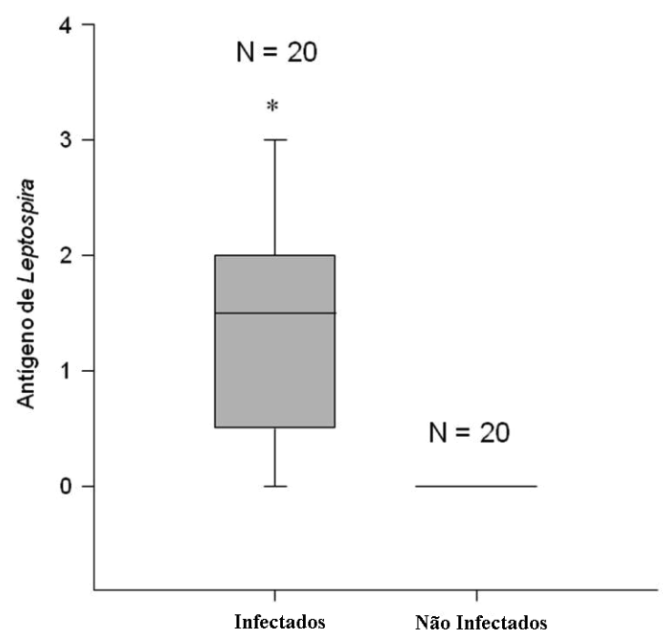

Fig.10. Semi-quantitative analysis of the presence of Leptospira antigen (median percentile scores between 25 and 75) in the kidney of dairy cows naturally infected by L. interrogans and uninfected control. $\mathrm{N}=$ number of animals per group. ${ }^{*} \mathrm{P}<0.05$ (Mann Whitney).

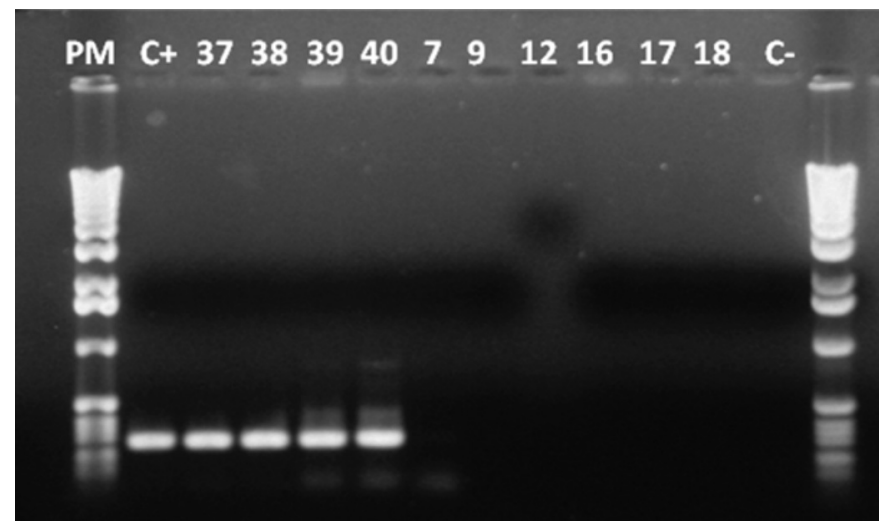

Fig.11. 1.5\% agarose gel stained with ethidium bromide showing product-specific PCR obtained with DNA extracted from urine samples of cattle naturally infected with Leptospira spp. $\mathrm{C}+=$ positive control L. spp serovar Hardjo, C- = control reagents used in PCR reaction.

\section{DISCUSSION}

Investigation of anti-Leptospira agglutinins in slaughterhouse animals is not the most appropriate way to determine disease prevalence in a certain region, usually because of the limited number and the diverse origin of the animals. Nevertheless, it enables us to obtain a safe record of infection and know which Leptospira serovar is more prevalent in cattle according to their place of origin. It can be inferred that $38.3 \%$ of a total of 60 cows originating from the Parnaiba dairy basin were infected by Leptospira spp. This infection is likely a reflection of natural exposure, since cattle vaccination is not practiced in the region.

Serologic evidence has shown the importance of serovar Hardjo (Hardjo bovis/Sponselee, Hardjoprajitno/CTG and Hardjoprajitno/OMS), occurring in $86.9 \%(20 / 23)$ of seroreactive animals, followed by serovars Bratislava,
$4.34 \%(1 / 23)$, Icterohaemorragiae $4,34 \%(1 / 23)$ and Pomona $4.34 \%$ (1/23). Hardjo also predominated in dairy cattle in different states of the Brazil, such as São Paulo (Favero et al. 2001), Minas Gerais (Moreira et al. 1993, Araújo et al. 2005), Pernambuco (Oliveira et al. 2001), Amazonas (Homem et al. 1993), Rio de Janeiro (Lilenbaum \& Souza 2003) and Piauí (Mineiro et al. 2007). Moreover, Bratislava is the most commonly encountered serovar $(25.4 \%)$ in northern Spain, followed by the serovar Hardjo (8.2\%) (Atxaerandio et al. 2005). The variations observed were attributed to differences in environmental and climatic conditions.

Forty animals were included in the series of pathological changes. Twenty of these animals (50\%) had kidney disorders. Lesions were located either in the cortical, corticomedullary or medullary region. It is known that the preferential site of renal injury in leptospirosis is the tubulointerstitial space. There is evidence of greater injury to the proximal tubules (Sitprija et al. 1980, Barnett et al. 1999). Leptospires adhere to the surface and release toxins, damaging the tubular epithelium (Alves et al. 1987). Although no control or serology tests were done to rule out other diseases, it was assumed that renal inflammatory lesions were due to leptospirosis because this alteration was significantly higher in infected animals than uninfected controls. In addition, leptospires were found in the renal tubules of five seropositive animals $(12.5 \%)$ by Warthin Starry staining. The percentage of leptospires found in this study was lower than that observed by Yener \& Keles (2001) and higher than that observed by Saglam et al. (2003), both in cattle.

Renal tubulointerstitial lesions, such as interstitial nephritis and tubular atrophy were found in all seropositive animals (100\%) but in none of the seronegative animals. Glomerular lesions of minimal intensity were also observed (Sitprija et al. 1980, Alves et al. 1989). However, glomerular lobulation, thickening of the glomerular capillary basement membrane and the presence of protein material in Bowman's capsule were highlighted.

Lesions observed in the pulmonary and hepatic parenchyma were probably due to microorganism multiplication in the leptospiremic phase. However, with the appearance of antibodies in the serum as confirmed by MAT, leptospires were eliminated from the liver and most organs involved, remaining in the kidneys (Oliveira et al. 2005).

Immunohistochemistry is a sensitive technique for detection of Leptospira sp. or leptospiral antigen in kidney tissue. Antigen was more intensely observed in epithelial and interstitial cells than in other renal structures, suggesting that these are the preferential sites of action of leptospires in the kidneys. These results corroborate those of other studies conducted in humans, hamsters and cattle (Alves et al. 1989, Haanwinckel et al. 2004, Silva et al. 2005). Furthermore, a greater num- 
ber of leptospiral antigens were found in the glomerular cells of infected animals compared to uninfected animals, demonstrating that the glomeruli are also affected during the course of cattle infection.

PCR revealed the presence of Leptospira DNA in the urine of 20 seropositive cows (100\%) and in the kidney tissue of 10 animals (50\%). In seronegative animals, Leptospira DNA was not observed, either in the urine or renal tissue. Serology associated with histopathology, immunohistochemistry and PCR are effective diagnostic methods for confirming cattle infection. The results of this study are in agreement with those suggesting that PCR may be an alternative for Leptospira detection in tissue and urine samples (Baskerville 1984, Gravekamp 1993, Gerritsen et al. 1994, Magajevski et al. 2007). In cattle, the urine of $52.5 \%$ animals tested positive for Leptospira infection by PCR (Gravekamp 1993).

\section{CONCLUSIONS}

Leptospira infection in cattle occurs in the Dairy Basin of Parnaíba/PI and the most frequent serovar found was Hardjo.

Changes were observed in the kidneys, lungs, liver and uterus of these animals, impairing their productive and reproductive performance.

Leptospiral antigen and DNA were detected in the renal tissue and urine, making this disease a major public health problem.

\section{REFERENCES}

Alves V.A.F., Siqueira S.A. \& Pestana C.B. 1989. Patologia da leptospirose. Análise crítica dos aspectos morfológicos e imuno-histoquímicos relevantes para a compreensão da patogenia. Revta Inst. Adolfo Lutz 49:7580 .

Alves V.A.F., Vianna M.R., Yasuda P.H. \& Brito D.T. 1987. Detection of leptospiral antigen in the human liver and kidney using na immunoperoxidase staining procedure. J. Pathol. 151:125-131.

Araújo V.E.M., Moreira E.C., Naveda L.A.B., Silva J.A. \& Contreras R.L. 2005. Frequency of anti-Leptospira interrogans agglutinins in bovine serum samples in Minas Gerais, Brazil, 1980 to 2002. Arq. Bras. Med. Vet. Zoot. 57:430-35.

Atxaerandio R., Aduriz G., Ziluaga I., Esteban J.I., Maranda L. \& Mainar-Jaime R.C.l. 2005. Serological evidence of Leptospira interrogans serovar Bratislava infection and its association with abortions in cattle in northern Spain. Vet. Rec. 156:376-380.

Barnett J.K., Barnett D., Bolin C.A., Summers T.A., Wagar E.A., Cheville N.F., Hartskeerl R.A. \& Haake D.A. 1999. Expression and distribution of leptospiral outer membrane components during renal infection of ramsters. Infect. Immun. 67:853-861.

Baskerville A. 1984. Histopathological aspects of diagnosis of leptospirosis, p.33-43. In: Ellis W.A. \& Little T.W.A. (Eds), The Presente State of Leptospirosis Diagnosis and Control. Northern Ireland.

Brasil 2000. Instrução Normativa no. 3, de 17 de janeiro de 2000. Ministério da Agricultura, Pecuária e Abastecimento, Brasília.

Ellis A.W. 1994. Leptospirosis as a cause of reproductive failure. Vet. Clin. North Am., Food Anim. Pract. 10:463-478.

Faine S., Adler B., Bolin C. \& Perolat P. 1999. Leptospira and Leptospirosis. $2^{\text {nd }}$ ed. Medisci, Melbourne.
Favero M., Pinheiro S.R., Vasconcellos S.A., Morais Z.M., Ferreira F. \& Ferreira Neto J.S. 2001. Leptospirose bovina: variantes sorológicas predominantes em colheitas efetuadas no período de 1984 a 1997 em rebanhos de 21 estados do Brasil. Arqs Inst. Biológico, São Paulo, 68:29-35.

Gerritsen M.J., Koopmans M.J., Peterse D. \& Olyhoek T. 1994. Sheep as maintenance host for Leptospira interrogans serovar hardjo subtype hardjobovis. Am. J. Vet. Res. 55:1232-1237.

Givens M.D. 2006. A clinical evidence-based approach to infectious causes of infertility in beef cattle. Theriogenology 66:648-654.

Gravekamp C., Van de Kemp H., Franzen M., Carrington D., Van Eys G.J.J.M, Everard C.O.R., Hartskeerl R.A. \& Terpstra W.J. 1993. Detection of seven species of pathogenic leptospires by PCR using two sets of primers. J. Gen. Microbiol. 139:1691-1700.

Haanwinckel M.C.S., Megid J. \& Souza L.C. 2004. Avaliação da prova de imunoperoxidase como recurso diagnóstico na leptospirose animal. Arqs Inst. Biológico, São Paulo, 71:293-301.

Heinemann M.B., Garcia J.F., Nunes C.M., Morais Z.M., Gregori F., Cortez A., Vasconcellos S.A., Visintin J.A. \& Richtzenhain L.J. 1999. Detection of leptospires in bovine semen by polymerase chain reaction. Aust. Vet. J. 77:32-34.

Homem V.S.F., Heinemann M.B., Morais Z.M., Vasconcellos S.A., Ferreira F. \& Ferreira Neto J.S. 2001. Estudo epidemiológico da leptospirose bovina e humana na Amazônia oriental brasileira. Revta Soc. Bras. Med. Trop. 34:173-180.

Huttner M.D., Pereira H.C.P. \& Tanaka R.M. 2002. Pneumonia por leptospirose. J. Pneumol. 28:229-232.

Lilenbaum W. \& Souza G.N. 2003. Factors associated with bovine leptospirosis in Rio de Janeiro, Brazil. Res. Vet. Sci. 75:249-251.

Luna L.G. 1968. Manual of the Histologic Staining Methods of the Armed Forces Institute of Pathology. $3^{\text {rd }}$ ed. McGraw Hill, New York. 258p.

Magajevski E.S., Gírio R.J.S. \& Meirelles R.B. 2007. Pesquisa de Leptospira em feto de vacas abatidas no Estado de São Paulo, Brasil. Arqs Inst. Biológico, São Paulo, 74:67-72.

Mineiro A.L.B.B., Bezerra E.E.A., Vasconcellos S.A., Costa F.A.L. \& Macedo N.A. 2007. Leptospiral infection in bovine and its association with reproductive failure and climatic conditions. Arq. Bras. Med. Vet. Zootec. 59:11031109.

Moreira E.C., Silva J.S., Viana F.C., Santos W.L.M., Anselmo F.P. \& Leite R.C. 1993. Leptospirose bovina. I. Aglutininas antileptospira em soros sangüíneos de bovinos em Minas Gerais. Arq. Esc. Vet. Univ. Fed. Minas Gerais 31:375-378.

Nally J.E., Chantranuwat C., Wu X.Y., Fishbein M.C., Pereira M.M., Da Silva J.J., Blanco D.R. \& Lovett M.A. 2004. Alveolar septal deposition of immunoglobulin and complement parallels pulmonary hemorrhage in guinea pig model of severe pulmonary leptospirosis. Am. J. Pathol. 164:1115-1127.

Oliveira A.A.F., Mota R.A., Pereira G.C., Langoni H., Souza M.I., Navegantes W.A. \& Sa M.E.R. 2001. Seroprevalence of bovine leptospirosis em Garanhuns municipal district, Pernambuco State, Brazil. Onderstepoort J. Vet. Res. 68:275-279.

Oliveira R.C., Freitas J.C., Silva F.G., Souza E.M., Delbem A.C.B., Alves L.A., Muller E.E., Balarim M.S., Reis A.C.F., Batista T.N. \& Vasconcellos S.A. 2005. Diagnóstico laboratorial da leptospirose em um cão utilizando diferentes técnicas. Arqs Inst. Biológico, São Paulo, 72:111-113.

Pirani C.L. 1994. Evaluation of kidney biopsy specimes, p.85-115. In: Tisher C.C. \& Brenner B.M. (Eds), Renal Pathology: With clinical and functional correlations. J.B. Lippincott Company, Philadelphia.

Saglam Y.S., Temur A. \& Aslan A. 2003. Detection of leptospiral antigens in kidney and liver of cattle. Dtsch. Tierärztl. Wochenschr. 110:75-77.

Scanziani E., Sironi G. \& Mandelli G. 1989. Immunoperoxidase studies on leptospiral nephritis of swine. Vet. Pathol. 26:442-444. 
Silva F.G., Freitas J.C., Anzai E.K., Hashimoto V.Y., Giraldi N., Delbem A.C.B., Bracarense A.P.F.R.L., Reis A.C.F. \& Vasconcellos S.A. 2005. Leptospirosis detection in kidney, liver and uterus of cows slaughtered in Paraná State, Brasil. Braz. J. Microbiol. 36:38-42.

Sitprija V., Pipatanagul V., Mertowidjojo K., Boonpucknavig V. \& Boonpucknavig S. 1980. Pathogenesis of renal disease in leptospirosis: Clinical and experimental studies. Kidney Int. 17:827-836.
Wohl J.S. 1996. Canine leptospirosis. Compend. Contin. Educ. Pract. Vet. 18:1215-1241.

Yang C.W., Wu M.S. \& Pan M.J. 2001. Leptospirosis renal disease. Nephrol. Dial. Transplant.16:73-77.

Yener Z. \& Keles H. 2001. Immunoperoxidase and histopathological examinations of leptospiral nephritis in cattle. J. Vet. Med. A, Physiol. Pathol. Clin. Med. 48:441-447. 